\title{
INVESTIGATING WORK ETHIC AND ITS PERTINENT FACTORS: A CROSS-SECTIONAL STUDY IN SHIRAZ, IRAN
}

\author{
JAHANGIR JAHANGIRI, MOHAMMAD HASSAN HEIDARIAN, MOHAMMAD \\ TAGHI IMAN
}

\begin{abstract}
:
The main purpose of this paper is to study socio-cultural and economic factors related to work ethic. Accordingly the first step of the study was to test and analyze the subject of the research. Then the national and international researches related to the subject were studied and some of them were reported. Subsequently, various sociological theories were reviewed and, finally, Weber's theory was chosen as the theoretical framework of the research. The statistical population of the study consisted of nurses working in private and public hospitals of the Shiraz for which 390 individuals were selected as the study sample through multi-stage cluster sampling method. A questionnaire was used for data collection. The validity of the questionnaire was verified through the validity of the translation and facial validity, and its reliability was confirmed by Cronbach's alpha coefficient. The data gathered by questionnaires were analyzed using SPSS. After analyzing the data and testing the hypotheses, the findings of the research were presented in descriptive and inferential sections. The descriptive findings of the research indicate that the work ethic has been at a low level for $2.1 \%$ of the respondents, at a medium level for $69.2 \%$ of the respondents, and at a high level for $28.7 \%$ of the respondents. In the present study, 14 hypotheses were developed, where 4 hypotheses were confirmed via one-way analysis of variance (ANOVA) after analyzing the hypothesis. The findings in this section of the data analysis showed that 4 variable, including place of birth, social class, media consumption, and religious identity have a significant relationship with work ethic. In addition, the results of multivariate regression analysis showed that four variables, i.e. religious identity, media consumption, place of birth, and work history, with 15.6, 7.5, 1.3, and 1 percent, respectively, predict $25.4 \%$ of the total work ethic changes. The obtained results are analyzed and discussed in final section of the study.
\end{abstract}

\section{Keywords:}

ethic, work ethic, work, nurses, hospital, Shiraz.

JEL Classification: $\mathrm{A} 13, \mathrm{C} 30, \mathrm{C} 83$

\section{Authors:}

JAHANGIR JAHANGIRI, Shiraz University, Iran (Islamic Republic of), Email: jjahangiri@gmail.com MOHAMMAD HASSAN HEIDARIAN, Shiraz University, Iran (Islamic Republic of), Email: mohammadhassanheidarian@gmail.com

MOHAMMAD TAGHI IMAN, Shiraz University, Iran (Islamic Republic of), Email: iman@shirazu.ac.ir

\section{Citation:}


JAHANGIR JAHANGIRI, MOHAMMAD HASSAN HEIDARIAN, MOHAMMAD TAGHI IMAN (2018). Investigating Work Ethic and its pertinent Factors: a Cross-sectional Study in Shiraz, Iran. International Journal of Social Sciences, Vol. VII(2), pp. 17-35., 10.20472/SS.2018.7.2.002 


\section{Introduction}

In modern world, work is not only a means for subsistence, but also a determinant factor that affects all personal and social aspects of life. It also indicates the rate of development or under-development of the societies. Work determines the social position of a person; forms his values and procedures; affects lifestyles of the individuals; determines the time for going to the bed and waking up and also the leisure times; it affects social manners and behaviors, and even the place of residence, dressing, verbal culture and way of speaking, social relationships and friendships. It plays such a key role in our life that people usually identify a person by asking "what does he or she do?" Simply a word tailor, businessman, engineer, teacher, mechanic, physician, professor of the university, etc. provides a lot of information about personality and identity of a person. Therefore, work is not merely a means for subsistence; it rather determines lifestyles and social role of the individuals (Zandipour, 2005). Todays, the attitude towards work is a cultural attitude that attaches moral and positive values to doing the work properly and considers the work intrinsically valuable (Hamed, 2009). Therefore, today, more attention is paid to "work ethic". Generally speaking, it can be said that work ethic is a durable intellectual and mental foundation that forces a person to make certain decisions and perform certain actions while engaging in economic activities. In other words, when we talk about the work ethic in a society, we are referring to that part of the social culture that drives and strengthens economical and business-based activities and behaviors. Therefore, work ethic is not limited to work hours, it rather involves all economic behaviors including consumption, saving, investment, entrepreneurship etc. (MasoumiRad, 2011).

Since invention and development of the "work ethic" concept, based on Weber's ideas, today we can see that an extensive literature on this subject has emerged in various fields, including sociology. During the time, the work ethic that -according to Weber- led to the emergence of capitalism in the West, took distance from its religious origins and now it has turned into a global issue (Miller et al., 2002). Furthermore, investigating the factors related to it has become more important and attractive for scholars in different countries. The works are affected by different factors in different countries. Cultural, social, economical, psychological, and political features of each society undoubtedly affect the works and lifestyles of people living in that society. With the acceleration of industrialization and modernization across the world, the definition of work has undergone substantial changes compared to the past. Nowadays, old cultural metrics no longer can be used to evaluate the culture and ethic of the work in a society. Given the increasing pace of developments and the level of competition in the cultural and economic context of today's world, adopting an efficient and scientific approach to investigate work concept seems necessary for country's development; an approach which has started in industrial and developed countries since a long time ago. Iranian society is in a transition. In such society, we are witness of the presence and domination of traditional values and norms. In some cases, family, kinship group and tribe determine the fate of the person. On the 
other hand, since the familiarity and extensive contacts between Iran and the West, particularly in the recent years and under the influence of globalization, we have witnessed some very serious alterations in Iranian community. Some of the most prominent factors that all have extended the scope of the changes include the development of public education, increase academic centers all over the country and providing access to higher education, especially for women and girls and their further entrance into social and economic activities, increase the range of radio and television networks across the country and increase the TV channels and their manufactured programs, increase public access to the telephone, newspapers, books, mobile, satellite and the internet, and thus facilitate communication, enhance communication with the outside world, increasing international exchanges,. As a result, Iranian culture, willingly or unwillingly, has been affected by these changes (Jahangiri et al., 2016). The main purpose of this paper is to study socio-cultural and economic factors related to work ethic.

\section{Problem statement and research necessity}

Observing ethics is one of the most important foundations of life, peace and social order. The societies can't survive without ethical order and to undermine ethical order of the society is to prevent the whole society from economic and social development, besides interrupting the path to human perfection in individuals. Therefore, to investigate ethical situation in Iranian society is of course a necessity. This necessity will be felt more, if we consider the fact that according to the dominant narratives of ethical situation in Iran, the country is in a critical situation and down an ethical retrogressive path. Over the past years, concerns regarding general ethics in society have been raised by various social, cultural and political parties. From an official and administrative standpoint, this concern is a long-standing one. Concerns regarding the status of general ethics in today's Iranian society and the "feeling of losing society" have crossed the epistemological and methodological boundaries between general ethics and work ethic. For example, the critical situation of work ethic as a function of public morality can easily be seen in various professions i.e. driving ethics, massive embezzlement in the banking system and widespread financial corruption in sports (Hajiani, 2014: 14).

The studies by experts on social issues in Iran, managers, cultural and political elites, and sociologists indicate that culture and work ethic in Iran are in a lower level compared to industrial and developed countries and societies. These claims are mostly based on comparisons between productivity and useful daily work hours in Iran and other countries. For example, in Japan or similar developed countries, each person spends an average of 7 hours for useful daily works, while in Iran this amount is less than 1 hour. Escaping from work, lack of motivation, wasting time at work, bewildering the clients and many other examples, indicate the critical status of work ethic among the Iranians. The Iranian authorities and social-political leaders have also emphasized on this issue in their messages and speeches. According to the most of the experts in economy, work ethic in Iran is undesirable and so it is necessary to consider the lack of proper work ethic in 
society as an economical, cultural and social problem, and accordingly appropriate studies to be conducted by scholars and experts aware of the social issues of the country with the aim of better identification of the status quo from the viewpoint of culture and work ethic and the factors affecting them (Moeedfar, 2007).

Work ethic is a key to understand development level of the countries (Ebadollahi Chanzanag and Nejat, 2010). Without adequate knowledge of the factors related to the work ethic, economical, cultural and social development of the societies will not be possible. Therefore, recognizing the factors affecting the development level of the societies is a prerequisite for macro social planning. Accordingly, present study seeks to identify some factors related to work ethic. This article is based on a field study and investigates economical, cultural and social factors related to work ethic among nurses working in Shiraz hospitals.

\section{Literature review}

The results of a study by Moeedfar (2006) whose statistical population included all staff of the public offices in Tehran province, showed that the level of work ethic in public agencies is higher than average. However, the sobering point highlighted by this study is the inverse relationship between work ethic and citizenship, economic position, social position and most importantly the level of education of the participants.

Tavassoli and Najjar Nahavandi (2008) conducted a research titled "The empirical study of ethics with emphasis on gender" with a quantitative approach and a survey method. The findings of this study indicated that gender does not affect work ethic, but other independent variables of this study were shown to be affected by gender. Roughly saying, job satisfaction affects men's work ethic more than women, work history and marital status do not affect work ethic, the number of children has a positive and direct impact on the perseverance and seriousness of the women. Annual leave has no impact on men's work ethic but it affects women's work ethic.

Assadi, Rad and Alizadeh (2009) conducted a study to investigate the work ethic with an emphasis on organizational factors among the staff of the state universities of Tabriz. Findings of this study show a significant but negative relationship between work ethic and organizational alienation, and a positive relationship between work ethic and collaborative management style and job satisfaction. In this study, no significant relationship was observed between work ethic and educational level of individuals.

Ronaghi and Feizi (2011) conducted a study to assess the work ethic among private banks' employees and developed a model to study work ethic and its impact on customer satisfaction. According to them, private bank employees in Iran respect and preserve work ethic and this positively affects satisfaction level among clients of these banks.

The results of a study by Ahmadi and Roosta (2011), conducted to compare work ethic between men and woman employees of 26 different branches of Islamic Azad University, showed that there is no significant relationship between gender and work ethic in general, 
but when investigating different aspects specifically, it turns out that women have better teamwork but less working commitment compared to men.

In a study titled 'Nurses' attitude toward supportive work climate affecting transfer of learning to job", Fahidi and Zeighami Mohammadi (2011) tried to clarify the factors associated with the transfer of knowledge gained from educational programs to work. The results of their study manifested that nurses have a moderate attitude toward the role of supportive conditions of the work environment in transferring learning into the work. The most support received from work environment was from colleagues and the least support received was recorded about the supply of equipment, providing enough time for the staff, and not assigning to conduct routines. The second factor affecting transfer of learning to work by nurses is the support of managers and supervisors. In general, this research suggests that the supportive environment of the workplace, such as support from managers and co-workers, encouragement and reduction of situational pressure are important and effective factors in the transfer of knowledge and skills to the work.

Ahmadi (2012) conducted a study to investigate the social factors affecting work ethic among the employees of the largest private organization of Iran, i.e. Islamic Azad University. The analytical results of the study showed that there is a significant and positive relation between participatory management, organizational justice, job satisfaction, age, work history, and work ethic. Also, in explaining the work-culture in terms of the sum of the independent variables of the study, job satisfaction and work history are respectively the strongest predictors of the work-culture and account for 0.18 of its variance.

Zolfaghari and Mohebi (2014) conducted a research titled "Types of Religiosity and Work Ethic". The purpose of this research was to study the work ethic and its various dimensions along with the multiple forms of religiosity and to analyze the relation between each aspect of the work ethic with different kinds of religiosity. In this research, in order to measure different kinds of religiosity a specific index was developed based on Sheppard typology. The results of the study indicated that there is a significant relationship between modernist religiosity and radical Islamism and the four dimensions of work ethic. New and intellectual understandings of the religion, manifested in the thoughts of modernists Islamists and radical Islamists who insist on using wisdom and discretion, also can have an effect on work ethic. On the other hand, such understandings indicate juxtaposition of religion and modernity, i.e. the adherence to religious values besides taking advantage of the modern phenomena in a society that while preserving its traditions, including religious traditions and values. This study also indicates that the level of work ethic is different between men and women in a way that men enjoy higher levels of work ethic rather than women.

The findings of a study by Ghanbari and Farshchi (2015), conducted on the staff of Bu-Ali Sina University, showed a significant positive relationship between the various dimensions of work ethic, so that the increase in work ethic in each one of the 
components, increases the work ethic in other components. Moreover, according to them, there is no significant relationship between gender, age and work ethic.

Sehhat et al. (2015) conducted a research titled "Positive Psychological Capital: The Role of Islamic Work Ethic in Tehran's Public Organizations". The main purpose of this research was to study Islamic work ethic and its impact on different aspects of human being personality, especially hope, flexibility, optimism, and effectiveness, among the employees. The results of the study showed that Islamic work ethic positively affects psychological capital and in general is very important for future researches.

Jahangiri et al. (2017) conducted a study to investigate the socio-cultural factors associated with work ethic among nurses working in state hospitals of Ilam. In this research, a MWEP questionnaire was used to measure work ethic and a researchermade questionnaire was used to measure cultural and social factors. The results of the research showed a direct relationship between work ethic and religious identity and media consumption. An inverse relationship was also reported between work ethic and social class.

Miller et al. (2002) published the results of their research titled "The Meaning and Measurement of Work Ethic: Construction and Initial Validation of a Multidimensional Inventory". The purpose of their study was to provide a comprehensive conceptual definition of "work ethic" in order to create a tool for measuring it, and also to validate this tool through a series of empirical research. In the end, Miller et al. developed a questionnaire titled "Multidimensional Work Ethic Profile (MWEP)". MWEP includes 7 dimensions with 65 items to measure work ethic. Since then, this questionnaire has been used and evaluated in many studies.

Ulrich et al. (2007) investigated the relationship between ethics and job satisfaction among nurses and social workers. $32.5 \%$ of the respondents reported that they feel helpless regarding ethical issues at workplace. $52.5 \%$ and $40 \%$ stated that they feel desperate and fatigue, respectively, when they are not able to solve the moral challenges. The results of the study also showed a positive and significant relationship between moral atmosphere and job satisfaction.

Lim et al. (2007) conducted a study titled "Interpreting and Developing the Korean and Shortened Version of the Multi-dimensional Work Ethic Profile". Given that previous studies conducted by MWEP had reported that filling the questionnaire takes a long time, Lim and colleagues decided to make it shorter in order to improve the productivity of the questionnaire. The English version of the MWEP includes 7 dimensions and each dimension consists of 7 to 10 items. At the end, Lim et al. developed a "Short Form of Korean Multidimensional Work Ethic Profile" (MWEP-SF) which included 35 items for 7 dimensions. The exploratory factor analysis and then the confirmatory factor analysis showed that the MWEP-SF is able to measure all of the 7 dimensions intended by MWEP developers and therefore can be used in other studies.

Herring (2007) carried out a qualitative research titled "Media Effects on Work Ethic among the Baby Boomers Generation." His findings indicate some specific educational 
effects, especially in defining work ethic and career paths, as well as the feeling of low self-esteem in unemployment periods. In addition, this study to some extent reflects the impact of resonance derived from the effects of TV social developments on generations of 1960s and 1970s. Discussing the impact of training on job success, the feeling of job insecurity and disappointment, and retirement benefits were amongst other issues highlighted in this study.

A study by Grady et al. (2008) on nurses and social workers working in four different states of America, also showed that teaching and practicing ethical issues during professional and vocational training was strongly associated with the ethical behavior of the nurses and social workers when performing their duties.

Catanzaro (2010) carried out a study titled "A Quantitative Study of Work Ethic and the Need for Success in a Peruvian Academic Population" as his doctoral dissertation. Adopting a quantitative approach, and a survey method, the study used a MWEP questionnaire to measure work ethic and a Needs Assessment Questionnaire (NAQ) to measure the needs. The results of the study showed that, contrary to popular belief, work ethic in Peru is not at a low level.

Chudzicka-Czupała et al. (2012) conducted a study titled "Compare the multi-dimensional profile of work ethic in two countries". The major aim of the study was to develop MWEP scale that formerly was developed by Miller and colleagues. Formerly, the English, Spanish and Korean versions of the MWEP were evaluated and used in other studies. Chudzicka-Czupała et al. tried to develop a polish version of the work ethic scale. After analyzing the data, they concluded that Polish version of MWEP is equal to its original and its English version and can be used in different studies.

Murtaza et al. (2014) carried out a study titled "The Impacts of Islamic Work Ethic on Organizational Citizenship Behaviors (OCBs) and Knowledge-Sharing Behaviors (KSBs)" on the employees of the Pakistan universities. The findings of the study suggested that Islamic work ethic has a positive impact on organizational citizenship and knowledge sharing. In other words, the employees with higher Islamic work ethic enjoyed a higher organizational citizenship and higher knowledge-sharing behaviors.

Abdullah and Halim (2016) conducted a study titled "The Impact of Work Ethic and Counterproductive Work Behavior on Employees of Public Sector". They concluded that misconduct in the workplace not only affects a single organization, but also the overall growth of society. The existence of a powerful work ethic guarantees the provision of full service to the general public by the staff. In sum, the findings of the study suggested that high levels of work ethic inhibit misconduct at work and during providing services.

Hoorn and Maseland (2013) tested Weber's famous thesis that Protestantism is associated with a stronger work ethic. In fact, they operationalized work ethic by examining the impact of religious denomination on the psychic costs of unemployment. For testing this Weberian thesis that Protestants/people from Protestant societies hurt from joblessness more than others because of their stronger work ethic, they used World Values Survey, covering 82 societies and comprising almost 150,000 individuals. Their 
results showed that unemployment has a negative effect on subjective well-being in general, but that Protestantism makes this effect much larger, establishing the contemporary relevance of Weber's insights on a specific Protestant work ethic more than a century after their inception.

Schaltegger and Torgler (2010) explored whether there is a Protestant specific work ethic or if work ethic can be explained by higher education. They found that religiosity is crucial for Protestant work ethic, which is compatible with Weber's thesis. They also found that work ethic is influenced by education, pointing to the important role of education not only for economic success but also for a commitment to work ethic. Hence, they found that with Protestants, education and religiosity explain hard work.

\section{Theoretical Framework}

Although Weber is recognized as the founder of interpretive sociology, he also sought to discover recurrence patterns and causal relationships in society (Seidman, 2013: 59). The design of present study from very beginning has been based on Weber's theory. Work ethic as a dependent variable of the research is a concept derived from Weber's works, especially Protestant Ethics and the Capitalist Spirit. According to Weber's theory, hard work is the foundation of work ethic. Only tedious and uninterrupted work can eliminate hesitation and confusion in humans and lead to certainty to salvation (Weber, $2015,91)$. To work more and more and to earn more and more money; this is the fundamental principle of work ethic. But it should be noted that the ultimate goal of hard working and earning more money is not getting wealthy. If a person seeks to gain wealth in order to be happy and unpardonable later, that wealth is nothing but a seduction of the laziness and dangerous enjoyment of life. To earn a fortune when is morally permissible and desirable that its goal is to do all assigned responsibilities perfectly, not leisure and self-indulgence (Weber, 2015, 130). In this kind of lifestyle, the goal is not to consume, rather is to gain. Therefore, on one hand, work ethic will lead to hard work and making more money and on the other hand strongly condemning leisure and self-indulgence and inviting the person to frugality. The immediate satisfaction of needs and work for enjoyment has nothing to do with ethics. One needs to work hard, save money and be able to delay the gratification. These principles logically lead to another principle: Selfreliance (Miller et al., 2002). If avoiding consumption simultaneously occurs with the search for wealth and hard work, the result is clear: capital is formed with compulsory frugality. The obstacles to the use of obtained wealth ultimately cause the wealth to be efficiently used in productive affairs (Weber, 2015: 137). In this case, the person obtains money more and relies less on other people; but self-reliance is not possible but through centrality of work in one's life. Prerequisite for any lucrative activity in the modern world is to restrict you to a specialized work and ignore many other aspects of life (Weber, 2015, 143). Man exists for his business, but not vice versa (Miller et al., 2002). Life should be dedicated to work and job responsibilities and the more people dedicate themselves to the work, the more they will enjoy from its benefits. Centrality of work in one's life 
recommends working hard and persistently, dispraising self-indulgence and trying to build wealth and not relying on others, all cause that time become increasingly important. In fact, wasting time is the first and most deadly sin of the man (Miller, 2002). Life is a short interval that needs to be spent on excellence. Wasting the precious time with wandering and talking too much, to lead a luxuries life and even sleeping more than what is necessary for your health, deserves absolute moral condemnation (Weber, 2015, 126). However, according to Weber's hypothesis, only those who adhere to ethical principles and values can realize such a hard life and austerity. Fraud, theft, lying, etc. have no place in work ethic intended here and earning wealth in any way possible is not legible and permitted (Weber, 2015:136). With regard to the above-mentioned facts, the work ethic intended by Weber has 7 dimensions: hard work, leisure, delay of gratification, selfreliance, centrality of work, wasted time, and morality/ethics.

In the present study, besides what was said before, paying attention to a fundamental point is of great importance. Although according to Weber, emergence of the spirit of capitalism stems from Protestant Labor Ethics, but in the end, he stresses that today, capitalism no longer relies solely on this particular religion and has taken distance from its roots (Miller et al., 2002). In Weber's opinion, deep religious movements, in fact, exerted a full impact on the economy, when the initial religious passion subsided. To seek heavenly world gradually bended with cold professional virtues, the religious roots became weakened and were replaced by a non-religious spirit. In fact, when piety was changing the world, the blessings of this world also exerted an inevitable and increasing force on human-beings; a force that nothing similar to that had never been known before. Nowadays, the spirit of pious and religious asceticism has fled its cage. The victorious capitalism that is based on mechanical foundations today, no longer needs the support of a particular religion (Weber, 2015: 144). In fact, at a historical turning point, a specific spirit and consequently what we call "Capitalism" emerged in the West. Then, capitalism spread throughout the world and promoted its own spirit. Therefore, what is being discussed today is no longer the Protestant work ethic it rather is a general work ethic and a universal issue. Over the past decades, various studies around the world have studied the relationship between different religions and work ethic. In the present study, the relationship between religion and work ethic is also important; especially with regard to Weber's research on various religions and their relationship with capitalism. Weber (1963) believed that Islam lacks the required foundations to create something like Western capitalism. This point has always been one of the controversial issues in Weber's Thought. According to many thinkers, this part of Weber's research is not wellsuited. For example, Turner (2001) declares that "The main point of Weber's statement is that Islam within itself didn't have the ethics compatible with the growth of rational capitalism. We can criticize this aspect of Weber's theory as a real mistake or at least an oversimplified matter (Turner, 2001: 290). Therefore, to study the relationship between religious identity (defined as Islamic identity in the present study) and work ethic in the present research are consistent with Weber's theory from two different aspects. On this 
basis, work ethic is not necessarily dependent on Protestant morality anymore and may exist in different societies and among people with different religions. The second aspect is the claim that Weber has specifically made about Islam. In this study, this section of Weber's theory is tested. In addition, paying attention to the fact that today capitalism is independent of its primary religious foundations and work ethic has turned to a widespread and universal, motivated us to study the relationship between media consumption and work ethic besides other variables. It seems that continuous promotion of issues such as hard work, earning wealth, attaches great importance to time, specialization and professionalize affairs, consumption, etc. in today's media is not unrelated to work ethic.

\section{Research hypotheses}

1. There is a significant relationship between age and work ethic.

2. There is a significant relationship between sex and work ethic.

3. There is a significant relationship between work history and work ethic.

4. There is a significant relationship between marital status and work ethic.

5. There is a significant relationship between the level of education and work ethic.

6 . There is a significant relationship between the birthplace and the work ethic.

7. There is a significant relationship between workplace and work ethic.

8. There is a significant relationship between ethnicity and work ethic.

9. There is a significant relationship between the social class and the work ethic.

10. There is a significant relationship between earnings and work ethic.

11. There is a significant relationship between education level of the respondents' mother and work ethic.

12. There is a significant relationship between education level of the respondents' father and work ethic.

13. There is a significant relationship between media consumption and work ethic.

14. There is a significant relationship between religious identity and work ethic.

\section{Methodology}

A quantitative approach and a survey method were used to examine the hypotheses mentioned above. Data collection was done by self-report questionnaire. In this study, economical, cultural and social factors as well as some of the demographical variables were considered as independent variables of the research and work ethic was considered as a dependent variable. Thus the independent variables of the study include age, gender, work history, marital status, educational level, place of birth, place of employment, ethnicity, social class, income level, use of the Internet, membership in social networks, use of Mobile-mediated instant-messaging applications, mother and father's education levels, media consumption and religious identity. To measure work ethic as a dependent variable, a variable with 7 dimensions covered by 60 items was used. The various dimensions of work ethic and the number and type of items related to 
them are: self-reliance (in the form of a Likert scale with 10 items), morality/ethics (in the form of a Likert scale with 5 items), leisure (in the form of a Likert scale with 10 items), hard work (in the form of a Likert scale with 10 items), centrality of work (in the form of Likert scale with 10 items), wasted time (in the form of a Likert scale with 8 items), delay of gratification (in the form of a Likert scale with 7 items). The independent Variables of the study were measured by a researcher made questionnaire and work ethic was measured by MWEP questionnaire. The validity of the questionnaire measured by translation and face validity, and its reliability were evaluated using Cronbach's alpha coefficient. Given that healthcare systems in all countries play a bigger and more influential role in people's lives than ever before (Hejduková and Kureková, 2017), the statistical population of the study includes the nurses working in public and private hospitals of Shiraz. In this study, the Cochran formula was used to determine the sample size. Given the large number of nurses working in public and private hospitals of Shiraz, i.e. 4765 individuals, according to the conducted calculations, the number of participants was estimated to be as large as 356 , assuming that the sampling error \pm 5 and a confidence level of $95 \%$, and for more certainty, this number was increased to 390 . In the present study, due to the lack of access to statistics and characteristics of nurses separately for each hospital, a multi-stage cluster sampling was used. To that end, first, according to the number and density of the hospital beds in different regions of the city, the clusters were determined. Then, in each of these clusters, the hospitals were randomly selected. In the next step, upon referring to each hospital, the list of the nurses was received from hospital authorities and according to that list the respondents were selected via simple random method. Data analysis was conducted at descriptive and inferential levels with SPSS 22. The descriptive findings of the present research are based on frequency distribution tables, mean of variables, inferential findings derived from correlation analysis, F-test, T-test and Pearson correlation coefficient. Also, for simultaneous examination of the relationship between different variables and dependent variable (multivariate analysis), stepwise multiple regression was used.

\section{Results}

The findings of the research indicate that $76.9 \%$ of the respondents were female and $23.1 \%$ were male. The minimum, maximum and average age of the respondents was 22 , 60 and 29.6 years, respectively. 39.7 percent of the respondents had a work history less than 5 years, 48.7 percent had a work history of 5 to 15 years and 11.5 percent of the participants had more than 15 years of experience. The number of single and married respondents was approximately equal and was $50.3 \%$ and $49.2 \%$, respectively. The majority of the respondents (90\%) had bachelor degree, $1.8 \%$ had associate's degree, $7.2 \%$ had undergraduate degree and $1 \%$ had $\mathrm{PhD}$ degree. $85.4 \%$ of the respondents were born at city and $14.6 \%$ of the participant were born in village. $74.9 \%$ of the respondents were working in public hospitals and $24.9 \%$ were working in private hospitals. In terms of ethnicity, $78.2 \%$ of the respondents were Fars, $10.8 \%$ were Lur, 
$6.2 \%$ were Turk, $1.8 \%$, were Kurd and $2.1 \%$ of them were from other ethnic groups. In terms of social class, 7.9 percent of the respondents belonged to the high social class, 63.1 percent belonged to the upper middle social class, 23.1 percent belonged to the lower middle social class, and $5.9 \%$ of them belonged to the low social class. The income of most of the respondents (53.3\%) was between one million and one and a half million. However, $5.6 \%$ of the respondents reported their income below 600 thousand Tomans, $11.5 \%$ of them reported their income between 600 thousand to 1 million Tomans, $25.4 \%$ reported their income between one and a half million to two million and a half dollars, and 4.1 percent of the respondents reported their income more than two and a half million Tomans. Most of the respondents (87.9\%) use Internet and $3.3 \%$ of the respondents were members of the Internet Social Networks. 85.6 percent of the respondents used instant-messaging applications on their mobile phones. The education level of the most respondents' mothers (67.7\%), as well as respondents' fathers (53.6\%) was lower than diploma. In terms of media consumption, $67.4 \%$ of respondents had low media consumption, $29.5 \%$ had medium media consumption and $3.1 \%$ had high media consumption. In terms of religious identity, $14.4 \%$ of the respondents had a low religious identity, $50.8 \%$ of them had a moderate religious identity, and $34.9 \%$ had a high religious identity. The work ethic of $1.2 \%$ of the respondents was at a low level, $69.2 \%$ at a moderate level and $28.7 \%$ at a high level.

Table 1: Descriptive Findings

\begin{tabular}{|c|c|c|c|c|c|c|c|c|}
\hline Variable & & Percent & Variable & & Percent & Variable & & Percent \\
\hline \multirow[t]{7}{*}{ Age } & $21-25$ & 8.30 & \multirow[t]{2}{*}{$\begin{array}{l}\text { Birth } \\
\text { place }\end{array}$} & City & 4.85 & \multirow{4}{*}{$\begin{array}{l}\text { Mother's } \\
\text { education } \\
\text { level }\end{array}$} & $\begin{array}{l}\text { Less than } \\
\text { diploma }\end{array}$ & 7.67 \\
\hline & $30-25$ & 6.36 & & Village & 6.14 & & Diploma & 6.23 \\
\hline & $31-35$ & 5.18 & \multirow[t]{2}{*}{$\begin{array}{l}\text { Work } \\
\text { place }\end{array}$} & $\begin{array}{l}\text { Private } \\
\text { Hospital }\end{array}$ & 9.24 & & $\begin{array}{l}\text { Associate } \\
\text { and } \\
\text { Bachelor }\end{array}$ & 7.7 \\
\hline & $36-40$ & 2.6 & & $\begin{array}{c}\text { Public } \\
\text { Hospital }\end{array}$ & 9.74 & & $\begin{array}{l}\text { Master and } \\
\text { higher }\end{array}$ & 1 \\
\hline & $41-45$ & 1.5 & \multirow[t]{5}{*}{ Ethnicity } & Lur & 8.10 & \multirow{4}{*}{$\begin{array}{c}\text { Father's } \\
\text { education } \\
\text { level }\end{array}$} & $\begin{array}{l}\text { Less than } \\
\text { diploma }\end{array}$ & 6.53 \\
\hline & $46-50$ & 2 & & Kurd & 8.1 & & Diploma & 9.26 \\
\hline & $\begin{array}{l}\text { More than } \\
50\end{array}$ & 8.0 & & Fars & 2.79 & & $\begin{array}{l}\text { Associate } \\
\text { and } \\
\text { Bachelor }\end{array}$ & 7.17 \\
\hline \multirow[t]{2}{*}{ Gender } & Female & 9.76 & & Turk & 2.6 & & $\begin{array}{c}\text { Master and } \\
\text { higher }\end{array}$ & 8.1 \\
\hline & Male & 1.23 & & Others & 1.2 & \multirow{3}{*}{$\begin{array}{l}\text { Media } \\
\text { Consumption }\end{array}$} & Low & 67.4 \\
\hline \multirow[t]{2}{*}{$\begin{array}{c}\text { Work } \\
\text { history }\end{array}$} & $\begin{array}{c}\text { Less than } 5 \\
\text { years }\end{array}$ & 7.39 & \multirow[t]{2}{*}{$\begin{array}{l}\text { Social } \\
\text { class }\end{array}$} & High & 9.7 & & Moderate & 29.5 \\
\hline & $5-15$ & 7.48 & & Upper & 1.63 & & High & 3.1 \\
\hline
\end{tabular}




\begin{tabular}{|c|c|c|c|c|c|c|c|c|}
\hline & & & & middle & & & & \\
\hline & $\begin{array}{c}\text { More than } \\
15\end{array}$ & 5.11 & & $\begin{array}{l}\text { Lower } \\
\text { middle }\end{array}$ & 1.23 & \multirow[t]{3}{*}{$\begin{array}{l}\text { Religious } \\
\text { identity }\end{array}$} & Low & 14.4 \\
\hline \multirow{3}{*}{$\begin{array}{l}\text { Marital } \\
\text { status }\end{array}$} & Single & 3.50 & & Low & 9.5 & & Moderate & 50.8 \\
\hline & Married & 2.49 & \multirow[t]{5}{*}{$\begin{array}{l}\text { Monthly } \\
\text { income }\end{array}$} & $\begin{array}{l}\text { Less than } \\
600.000\end{array}$ & 6.5 & & High & 14.4 \\
\hline & others & 5.0 & & $\begin{array}{l}600.000- \\
1 \text { million }\end{array}$ & 5.11 & \multirow[t]{3}{*}{ Work ethic } & Low & 2.1 \\
\hline \multirow[t]{3}{*}{$\begin{array}{c}\text { Education } \\
\text { level }\end{array}$} & $\begin{array}{c}\text { Associate's } \\
\text { degree }\end{array}$ & 8.1 & & $\begin{array}{l}1-1.5 \\
\text { million }\end{array}$ & 3.53 & & Moderate & 69.2 \\
\hline & $\begin{array}{c}\text { Bachelor } \\
\text { degree }\end{array}$ & 90 & & $\begin{array}{l}1.5-2.5 \\
\text { million }\end{array}$ & 4.25 & & High & 28.7 \\
\hline & $\begin{array}{l}\text { Master } \\
\text { Degree }\end{array}$ & 2.7 & & $\begin{array}{l}\text { More than } \\
2.5 \text { million }\end{array}$ & 1.4 & & & \\
\hline
\end{tabular}

Table 2 shows mean difference of work ethic in terms of respondent's place of birth. According to the results presented in the table, the average score of work ethic for the participants born in village (211.88) is higher than those born in the city (203.09). This difference is significant according to T-test and significance level (0.02) at a $95 \%$ confidence interval.

Table 2: The test of work ethic' mean-difference in terms of place of birth

\begin{tabular}{|l|l|l|l|l|l|l|}
\hline $\begin{array}{l}\text { Dependent } \\
\text { Variable }\end{array}$ & $\begin{array}{l}\text { Place of } \\
\text { Birth }\end{array}$ & Frequency & Mean & SD & T value & $\begin{array}{l}\text { Significance } \\
\text { level }\end{array}$ \\
\hline \multirow{2}{*}{ Work ethic } & City & 333 & 203.09 & 26.38 & -2.345 & 0.02 \\
\cline { 2 - 5 } & Village & 57 & 211.88 & 24.68 & & \\
\hline
\end{tabular}

Table 3 shows mean difference for work ethic in terms of social class. As the results show, the highest mean of work ethic belongs to the lower class (219.91). The upper middle, lower middle, and high class with 207.42, 199.59, and 182.55, respectively, are in the next places. This difference is significant according to the F-test and significance level $(0.000)$ at a $95 \%$ confidence interval.

Table 3: The test of work ethic means difference in terms of social class

\begin{tabular}{|l|l|c|c|c|c|c|}
\hline $\begin{array}{l}\text { Dependent } \\
\text { variable }\end{array}$ & $\begin{array}{l}\text { Social } \\
\text { Class }\end{array}$ & Frequency & Mean & SD & F value & $\begin{array}{l}\text { Significance } \\
\text { level }\end{array}$ \\
\hline Work ethic & High & 31 & 182.55 & 28.67 & 12.987 & 0.000 \\
\cline { 2 - 5 } & $\begin{array}{l}\text { Upper- } \\
\text { middle }\end{array}$ & 246 & 207.42 & 24.52 & & \\
\cline { 2 - 5 } & $\begin{array}{l}\text { Lower- } \\
\text { middle }\end{array}$ & 90 & 199.59 & 23.73 & & \\
\hline & Low & 23 & 219.91 & 31.77 & & \\
\hline
\end{tabular}


Table 4 shows the Pearson Correlation Coefficient for independent variables at an interval measurement level with work ethic. As it can be seen there is a significant relationship between media consumption (0.378) and religious identity (39.44) variables, and work ethic; namely, an increase in media consumption and religious identity leads to an increase in work ethic. The hypothesis are significant at a 95\% confidence interval.

Table 4: Pearson Correlation Coefficient between Independent Interval Variables and Work ethic

\begin{tabular}{|l|l|l|l|l|l|}
\hline \multicolumn{2}{|c|}{ Correlation coefficient } & \multicolumn{1}{|c|}{ Mean } & \multicolumn{1}{|c|}{ SD } & \multicolumn{1}{c|}{$\begin{array}{c}\text { Pearson } \\
\text { coefficient }\end{array}$} & significance \\
\hline $\begin{array}{l}\text { Media } \\
\text { Consumption }\end{array}$ & Work Ethic & 11.585 & 3.375 & 0.378 & 0.000 \\
\hline $\begin{array}{l}\text { Religious } \\
\text { identity }\end{array}$ & Work Ethic & 19.313 & 5.348 & 0.394 & 0.000 \\
\hline
\end{tabular}

Table 5 shows the results of multivariable regression analysis. For the purposes of the study, a stepwise multi-variable regression statistics was used. In this method, different variables will be entered into the equation in order of their importance in determining the dependent variable; the variables that have no effect on determining the dependent variable will be discarded. The results indicate that with a significant level, the regression equation has three steps. In each step, one variable was entered into the equation. As shown in the table, religious identity, media consumption, place of birth (born in a village), and work history, respectively, have the most relationship with work ethic. In other words, among all the independent variables that were entered into multivariate regression analysis, only four variables including religious identity, media consumption, place of birth, and work history explain the work ethic. These four variables account for $25.4 \%$ of the variance of work ethic variable in total, where the share of media consumption is $7.5 \%$, the share of place of birth is $1.3 \%$ and the share of work history is $1 \%$. Correlation coefficient of these four variables in total is 0.504 . The beta values indicate that all four independent variables entered in the regression are directly related to the dependent variable. That is, an increase in religious identity, media consumption, place of birth (born in a village) and work history leads to an increase in work ethic.

Table 5: The results of stepwise multiple regression to predict work ethic

\begin{tabular}{|c|c|c|c|c|c|c|c|}
\hline Step & $\begin{array}{c}\text { The entered } \\
\text { variable }\end{array}$ & $\begin{array}{c}\text { Correlation } \\
\text { Coefficient } \\
(\mathrm{R})\end{array}$ & $\begin{array}{c}\mathrm{B} \\
\text { coefficient }\end{array}$ & $\begin{array}{c}\text { Beta } \\
\text { Coefficient }\end{array}$ & T-test & $\begin{array}{c}\text { Significance } \\
\text { level }\end{array}$ & $\begin{array}{c}\text { Coefficient of } \\
\text { determination }\left(\mathrm{R}^{2}\right)\end{array}$ \\
\hline 1 & $\begin{array}{c}\text { Religious } \\
\text { identity }\end{array}$ & 0.394 & 1.562 & 0.318 & 6.888 & 0.000 & 0.156 \\
\hline 2 & $\begin{array}{c}\text { Media } \\
\text { Consumption }\end{array}$ & 0.481 & 2.228 & 0.286 & 6.183 & 0.000 & 0.231 \\
\hline 3 & $\begin{array}{c}\text { Place of } \\
\text { Birth }\end{array}$ & 0.494 & 8.668 & 0.117 & 2.639 & 0.009 & 0.244 \\
\hline 4 & Work History & 0.504 & 5.095 & 0.097 & 2.196 & 0.029 & 0.254 \\
\hline
\end{tabular}




\section{Discussion and conclusion}

The major purpose of the present study was to investigate the economical, cultural and social factors associated with work ethic. 390 nurses working in hospitals of Shiraz were studied as a research sample. The theoretical framework of the study was based on Weber's theory. In this research, based on the theoretical framework, 14 hypotheses were raised, where four hypotheses were approved. According to the results, there is a significant relationship between the place of birth, social class, media consumption and religious identity, and work ethic. Weber's theory regarding the relationship between place of birth and work ethic was approved. The respondents born in the villages obtained a higher average score for work ethic. Weber's emphasis on educational background helps to explain this finding. The villagers are more accustomed to hard work and less to leisure. Moreover, according to findings, villagers are more committed to the ethics and postpone their gratification. According to the experimental results of this study, Weber's theory regarding the relationship between social class and work ethic is confirmed. According to Weber, social class is associated with work ethic and the progressive classes have a higher degree of ethics. Besides confirming the hypothesis regarding the existence of a significant relationship between social class and work ethic, the results indicate that people belonging to the lower social classes have a higher average of ethics. In fact, people who belong to the lower social class work harder, have fewer opportunities for leisure and self-indulgence, waste less time, and work plays a central role in their life. The members of the lower social class, as they are more in need and desire for advancement, devote their lives to the work more than others. According to the constant promotion of ideas such as encouragement of hard work and more income, promoted importance of time embodied in slogans like "time is gold", specialization and professionalism, consumption and etc. in today's media, in the present study, the variable of media consumption was defined and implemented and its relationship with work ethic was investigated. The experimental results of the study confirm the hypothesis that there is a significant relationship between media consumption and work ethic. This relationship is direct, so that the more the media consumption of the respondent increases, the more his or her work ethic will increase. In fact, through this hypothesis, that part of Weber's theory which implies the state of work ethic in the world today is confirmed. Work ethic, which is no longer reliant on its roots in a particular religious conception, has turned to a global issue. The hypothesis on the existence of a meaningful relationship between religious identity and work ethic in the present study is the most fundamental hypothesis derived from Weber's theory. The findings of the study confirm this hypothesis and show a meaningful direct relationship between religious identity and work ethic. That is, when the religious identity of the respondent increases, the work ethic will also increase. Given that the religion of the participants was Islam then based on the results, it can be said that Islamic principles also cause hard work, leisure, delay of gratification, self-reliance, centrality of work, wasted time and morality/ethics. Also, the results of multivariate analysis showed that the religious identity of the respondents has the highest share 
(15.6\%) in determining work ethic. In addition, media consumption, being born in a village, and work history accounted for $7.5 \%, 1.3 \%$, and $1 \%$ of work ethic changes, respectively.

\section{References}

Abdullah, A., \& Halim, F. W. (2016). The Influence of work ethic and conterproductive work behavior of civil servants. Journal of Technology Management and Business, 3(1), 1-14.

Ahmadi, Sirous. (2012). Investigating Work Culture and the Social Factors Affecting it, Applied Sociology, 23(2), 21-40.

Ahmadi, Sirous, Loreasb, Roosta. (2011). A Comparative Study of Women and Men's Work Culture, Women's Sociology, 2(2), 39-58.

Asadi, Hossein, Rad, Firooz, Alizadeh, Mohammadbagher. (2009). Investigating Work ethic with Emphasis on Organizational Factors (A Case Study of Employees of Public Universities of Tabriz), Sociological Studies: 2(5), 29-44.

Bazerman, M., \& Tenbrunsel, A. (2011). Ethical Brakedowns. Harvard Business Review, 89(4), 58-65.

Byrne, E. F. (1990). Work, inc.: A philosophical inquiry. Philadelphia: Temple Univ. Press. Catanzaro, Richard D. (2010). Quantitative analysis of work ethic and need to achieve in a pruvian university population (Doctoral dissertation, University of Phoenix).

Chudzicka-Czupała, A., Cozma, I., Grabowski, D., \& Woehr, D. J. (2012). A comparison of the multidimensional work ethic profile across two countries. Journal of Management and Bussiness, 2 , 14-33.

Ebadollahi Chanzanagh, Jafar Nejat, Hamid. (2010). Values and Work Ethic: A Case Study of Rasht Teachers), Journal of Social Studies in Iran: 4(3), 108-133.

Fine, R. (1983). The Protestant ethic and the analytic ideal. Political Psychology, 4, 245-264. https://doi.org/10.2307/3790937

Furnham, A. (1990). The Protestant work ethic: The psychology of work-related beliefs and behaviours. London: Routledge.

Grady, C., Danis, M., Soeken, K. L., O'Donnell, P., Taylor, C., Farrar, A., \& Ulrich, C. M. (2008). Does ethics education influence the moral action of practicing nurses and social workers?. The American Journal of Bioethics, 8(4), 4-11. https://doi.org/10.1080/15265160802166017

Ghanbari, Sirous, Farshchi, Fatemeh. (2015). Investigating Work Ethic of the Employees of Bu-Ali Sina University, Ethics, 5(18), 173-202.

Gurny, Patrick J. (1981). Historical Origins of Ideological Denial: The Case of Marx in American Sociology. American Sociologist, 16, 196-201.

Hajiani, Ebrahim. (2014). Sociology of Ethics: An Analysis of the Status of Social Ethics in Iran. Tehran: Jameeh Shenasan.

Hamed. Bita (2009). Social factors related to youth attitude towards work, A case study of 18-26 year old youths of Kermanshah. Youth Research, Culture and Society, 2, 77-97.

Hejduková, P., Kureková, L (2017). Performance and sustainable of healthcare systems and approaches to its measuring and evaluating. International Journal of Social Sciences, $\mathrm{VI}(2), 32-43$. https://doi.org/10.20472/SS2017.6.2.003

Herring, J. L. (2007). Media influence on the work ethic among the baby boom generation (Master dissertation, lowa State University).

Hoorn, A., Maseland, R. (2013). Does a Protestant work ethic exist? Evidence from the well-being effect of unemployment. Journal of Economic Behavior \& Organization, 91, 1-12. https://doi.org/10.1016/j.jebo.2013.03.038 
Jahangiri, J., Heidarian, M. H., Nouri Koochi, M. \& Shalbafan, M. (2017). Sociocultural Factors Related to Work ethic among Nurses: A Quantitative Study in Ilam, Iran. Shiraz $E$ Medical Journal,18(9):e57577. https://doi.org/10.5812/semj.57577

Jahangiri, J., Iman, M. T., Alizade, G. (2016). Sociological study of the relationship between national and ethnic identity in yasouj city. International Journal of Social Sciences, V(2), 44-57. https://doi.org/10.20472/SS2016.5.2.003

Lim, D. H., Woehr, D. J., You, Y. M., \& Allen Gorman, C. (2007). The translation and development of a short form of the Korean language version of the multidimensional work ethic profile. Human Resource Development International, 10(3), 319-331. https://doi.org/10.1080/13678860701515406

Maslow, A. H. (1943). A theory of Human Motivation. Psychological review, 50(4), 370. https://doi.org/10.1037/h0054346

Masoumi Rad, Reza. (2011). Promoting work ethic, a prerequisite for development and progress. Jam-e Jam Newspaper, 3173, 11.

Miller, Michael J., David J. Woehr, and Natasha Hudspeth. (2002). The meaning and measurement of work ethic: Construction and initial validation of a multidimensional inventory. Journal of Vocational Behavior 60(3),451-489. https://doi.org/10.1006/jvbe.2001.1838

Moeedfar, Saeed. (2007). Work Ethic as a Social Issue, Cultural Engineering, 2(14), 6-18.

Moeedfar, Saeed. (2006). Work Ethic and the Factors Affecting it among Employees of Public Departments, Social Welfare, 6(23), 321-341.

Murtaza, G., Abbas, M., Raja, U., Roques, O., Khalid, A., \& Mushtaq, R. (2016). Impact of Islamic work ethic on organizational citizenship behaviors and knowledge-sharing behaviors. Journal of Business Ethics, 133(2), 325-333. https://doi.org/10.1007/s10551-014-2396-0

Ronaghi, Mohammad Hossein, Feizi, Kamran. (2010). Presentation of the Model of Work Ethic of Iran's Private Banking Employees, Journal of Ethics in Science and Technology, 6 (2), 40-46.

Salomon, A. (1945). "German Sociology". In G. Gutvitch and W. F. Moore (eds.). Twentieth Century Sociology. New York: Philosofical Library: 586-614.

Schaltegger, C.A., Torgler, B. (2010). Work ethic, Protestantism, and human capital. Economics Letters, 107, 99-101. https://doi.org/10.1016/j.econlet.2009.12.037

Sehhat, S., Ashena, M., \& Parsa, S. (2015). Positive psychological capital: The role of Islamic work ethic in Tehran Public Organizations. Iranian Journal of Management Studies, 8(4), 545-566.

Seidman, S. (2013). Contested knowledge: Social theory today. New Jersey: John Wiley \& Sons.

Tavasoli, Gholam Abbas, Najjar Nahavandi, Maryam (2008). An Empirical Study of Work Ethic with Emphasis on Gender, Women in Development and Politics (Women's Research), 6(3), 39-60.

Ulrich, C., O'Donnell, P., Taylor, C., Farrar, A., Danis, M., \& Grady, C. (2007). Ethical climate, ethics stress, and the job satisfaction of nurses and social workers in the United States. Social Science \& Medicine, 65(8), 1708-1719. https://doi.org/10.1016/j.socscimed.2007.05.050

Van Ness, R. K., Melinsky, K., Buff, C. L., \& Seifert, C. F. (2010). Work ethic: Do new employees mean new work values?. Journal of Managerial Issues, 22(1), 10-34.

Weber, Max. (2015). The Protestant Ethic and the Spirit of Capitalis. (In Persian). Translated by Morteza Saghebfar. Tehran: Jami Publications.

Weber, Max. (1963). The Sociology of Religion. Boston, MA: Beacon.

Zandipur, Tayyibah. (2005). Pathology of Culture and Work Ethic, Advisory Researchs, 16, 47-62.

Zolfaghari, Abolfazl, Mohebi, Akram (2014). Types of Religiosity and Work Ethic: A Case Study of Employees of Zanjan University. Culture Strategy, 7(26), 147-177 
Zuzelo, P. R. (2007). Exploring the moral distress of registered nurses. Nursing Ethics, 14(3), 344-359. https://doi.org/10.1177/0969733007075870 